Home $>$ All Journals $\backslash$ Journal of Human Resources in Hospitality \& Tourism $\quad$ List of Issues $\quad$ Volume 18, Issue 4

$\checkmark$ Employees' retention in Nigeria's hospit ....

Journal of Human Resources in Hospitality \& Tourism >

Volume 18, 2019 - Issue 4

\title{
1,3324
}

Views CrossRef citations to date Altmetric

Original Articles

\section{Employees' retention in Nigeria's hospitality industry: The role of transformational leadership style and job satisfaction}

Folakemi Ohunakin $\square$, Adenike A. Adeniji, Olumuyiwa A. Oludayo, Adewale O. Osibanjo \& Oluseyi O. Oduyoye

Pages 441-470 | Published online: 17 Jun 2019

GS Download citation 凤 https://doi.org/10.1080/15332845.2019.1626795

A) Check for updates

\section{Sample our}

Sports and Leisure

Journals

> > Sign in here to start your access to the latest two volumes for 14 days

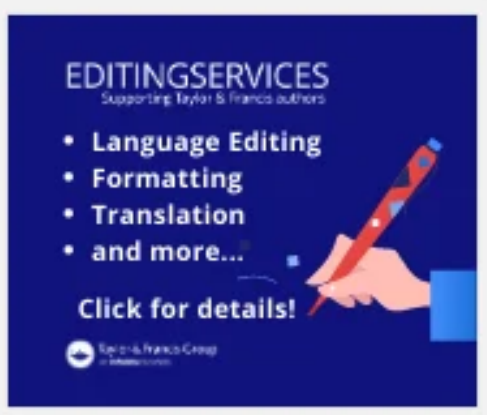

\section{Abstract}

Studies have shown the benefits and importance of leadership styles in service producing industries, to promote employees' overall well-being. This study was designed to examine 
interaction among the transformational style of leadership and job satisfaction, life satisfaction and turnover intention of employees. A total of 324 questionnaires were administered to the employees of six functioning universities' guesthouses in South-West, Nigeria. Structural Equation Modeling was used for assessing the fit of the model. Findings indicated that idealized influence, inspirational motivation, intellectual stimulation, and individualized consideration improved job satisfaction, and inversely affected turnover intention. In addition, life satisfaction was enhanced by idealized influence and individualized consideration, while inspirational motivation and intellectual stimulation had no positive effect on life satisfaction. Life satisfaction was positively associated with job satisfaction, and negatively associated with turnover intention. Recommendations were made for the hospitality organizations to embrace transformational leadership style to improve employees' work attitudes and behaviors. The managerial implications, study limitation and suggestion for further study were also discussed.

\section{Log in via your institution}

Loading institutional login options...

\section{$>\log$ in \\ Restore content access}

Log in to Taylor \& Francis Online

$>$ Restore content access for purchases made as guest

\section{Purchase options}

\section{PDF download + Online access}

- 48 hours access to article PDF \& online version 
- Article PDF can be printed

USD 45.00

\section{Issue Purchase}

- 30 days online access to complete issue

- Article PDFs can be downloaded

- Article PDFs can be printed

USD 410.00

․ Add to cart

* Local tax will be added as applicable

\section{Acknowledgement}

The authors wish to appreciate Covenant University for providing enabling platform to carry out this research. The authors also acknowledge the insightful suggestions and comments of the anonymous reviewers and the journal editor (Prof. Howard Adler). All these have improved this manuscript immensely.

\section{Related research 1}



Information for

Authors

Corporate partners

Editors

Librarians

Societies

Opportunities

Reprints and e-prints

Advertising solutions

Accelerated publication

Corporate access solutions

\section{Keep up to date}

Register to receive personalised research and resources by email

Sign me up

\section{(f) in

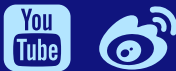

Open access

Overview

Open journals

Open Select

Dove Medical Press

F1000Research

Help and information

Help and contact

Newsroom

All journals

Books

\footnotetext{
Accessibility

Copyright @ 2021 Informa UK Limited Privacy policy Cookies Terms \& conditions 